Turkish Journal of Geriatrics

DOI: $10.31086 /$ tigeri.2018137970

2018;21 (1):81-86

Uygar DAŞAR ${ }^{1}$

\title{
ONE-YEAR RETROSPECTIVE EVALUATION OF HIP FRACTURE PATIENTS AGED MORE THAN 80 YEARS AND POSTOPERATIVELY MONITORED IN THE INTENSIVE CARE UNIT
}

\section{Abstract}

Introduction: As in all the world, expected life time has extended in our country as well which increases yearly operated elderly patient rate. Surgical intervention for hip fracture is one of the most common operations among them

Materials and Method: This study was done between 2014 and 2015 at Karabük Education and Research Hospital ICU. Who were older than age of 80 , operated for hip surgery and monitorized at ICU postoperatively included to study.

Results: The mean age of our patients was $84.65 \pm 3.36$ years, and 50 of them were female (69.44\%). 40 patients showed trochanteric femur fracture and 32 showed femoral neck fracture. Proximal femoral nail was implanted in 38 patients and partial hip prosthesis in 34 . Regional anesthesia was administered to 57 patients and general anesthesia to 15 . The hospital mortality rate was $16.6 \%$.When we grouped the patients as surviving $(60)$ or died (12), we found that the time before surgery was significantly longer for the died patients than for the surviving ones. The need for MV, duration of MV, and the need for inotropic agents were higher in died patients. The duration of ICU follow-up and hospital stay were longer for died patients. Other parameters showed no significant differences.

Conclusion: In our study, mental status of our patients and post-discharge conditions could not be evaluated. Not describing the cause of delay to the surgery and not recording patient satisfaction was other limitations. Therefore, we have decided to form a new research protocol for evaluating patient satisfaction and causes of delay to the surgery.

Keywords: Aged; Hip fractures; Mortality; Risk factors; Intensive care units

ARAŞTIRMA

CORRESPONDANCE

Uygar DAŞAR

Karabük University, Faculty of Medicine

Department of Orthopaedics and Traumatology

Karabük, Turkey

Phone: 903704330490

e-mail: udasar@yahoo.com

Received: 22/01/2018

Accepted: $27 / 02 / 2018$

Karabük University, Faculty of Medicine

Department of Orthopaedics and Traumatology Karabük, Turkey

This study was presented as a poster at the $26^{\mathrm{t}}$ of Turkish National Congress of Orthopedics.

\section{POSTOPERATIF YOĞUN BAKIM ÜNITESINDE TAKIP EDILEN 80 YAŞ ÜSTÜ KALÇA KIRIKLI HASTALARINBIR YILLIK RETROSPEKTIF DEĞERLENDIRILMESI}

Öz $_{z}$

Giriş: Tüm dünyada olduğu gibi ülkemizde de beklenen yaşam süresinin uzaması yıllık opere edilen yaşlı hasta yüzdesini artırmaktadır. Bu operasyonlar arasında en sık yapılanlardan biri kalça kırıklarına bağlı cerrahi girişimlerdir.

Gereç ve Yöntem: Bu araştırma, 2014-2015 yılları arasında Karabük Eğitim ve Araştırma Hastanesi Yoğun Bakım Ünitesinde yapılmıştır. Çalışmamıza, 80 yaş üzerinde, kalça kırığı nedeniyle operasyon geçirmiş olan ve postoperatif Yoğun Bakım Ünitesinde takibi yapılan hastalar alındı.

Bulgular: Hastaların yaş ortalaması $84.65 \pm 3.36$ yıl idi ve bunların 50 si kadındı. 40 hastada trokanterik femur kırığı ve 32 hastada femur boyun kırığı vardı. Proksimal femur çivisi 38 ve parsiyel kalça protezi 34 hastaya uygulandı. 57 hastaya rejyonel anestezi 15 hastaya genel anestezi verildi. Hastane mortalitesi \%16.6 idi. Hastalar yaşayan (60) ve ölenler (12) olarak gruplandırıldığında; ameliyat öncesi sure ölenlerde yaşayanlara göre uzundu. Mekanik ventilatör ihtiyacı ve mekanik ventilatör süresi ve inotrop ihtiyacı ölen hastalarda yüksekti. Yoğun bakım ünitesi ve hastanede yatış süreleri de ölen hastalarda uzundu. Diğer parametrelerde anlamlı bir fark yoktu.

Sonuç: Çalışmamızda hastalarımızın mental değerlendirmeleri ve taburcu edildikten sonraki değerlendirmeleri yapılamamıştır. Operasyon gecikme nedenlerinin tanımlanmamış ve hastamemnuniyetinin kaydedilmemiş olması diğer bir kısıtlılıklarındandır. Bunedenle operasyon gecikmenedenlerini ve hasta memnuniyetini değerlendirmek için yeni bir araştırmaprotokolü oluşurmaya karar verdik.

Anahtar sözcükler: Yaşlı; Kalça kırıkları; Mortalite; Risk faktörleri; Yoğun bakım üniteleri 


\section{INTRODUCTION}

As observed worldwide, life expectancy has been increasing in our country with a resultant increase in the annual rate of elderly patients who are operated. Surgical intervention for hip fracture is one of the most common surgeries among these patients $(1,2)$.

Elderly patients with cardiovascular and respiratory comorbid diseases experience increased complications and mortality rates (3-6). Previous national and international studies have investigated risk factors that affect morbidity and mortality in these patients, including age, sex, ASA score, present comorbid diseases, drug usage, type of fracture, surgical interventions, method of anesthesia, duration of surgery, patients' referral time to the emergency ward (IWH, in working hours; OWH, out of working hours), time before surgery, and intensive care unit (ICU) and hospital stay durations. However, the results were controversial. Some studies suggested ASA score as the primary factor to predict complications and mortality rate $(7,8)$. Age and male sex (9) and general anesthesia and time before surgery (10) were suggested as the primary factors causing high mortality rates. However, some other studies have reported contrasting results (11-13).

In this study, we aimed to analyze specific patients who were aged $>80$ years, classified as ASA III or IV, and postoperatively monitored the $I C U$, and conduct a descriptive research on the factors that affect the prognosis of patients at our clinic in our newly built hospital.

\section{MATERIALS AND METHOD}

This descriptive study was performed between 2014 and 2015 at the ICU of the Karabük Education and Research Hospital. Using our hospital's digital data bank and patient files, data were collected for patients who were aged $>80$ years, who underwent a hip surgery, and who were postoperatively monitored at the ICU. Patients who were aged $<80$ years, who did not require ICU care, and who died before the operation were excluded from the study.

A total of 72 patients were analyzed during the stated study period. The following patient characteristics and surgical parameters were recorded: age, sex, present comorbid diseases, time of referral to the emergency room (IWH/ $\mathrm{OWH}), \mathrm{ASA}$ score, fracture type [femoral neck fracture (FNF) or trochanteric femur fracture (TFF)], time before surgery, surgical intervention method [proximal femoral nail (PFN) or partial hip prosthesis $(\mathrm{PHP})$ ], anesthesia method [regional anesthesia (RA) or general anesthesia (GA)], duration of surgery, and the need for blood transfusion.

The following parameters were recorded during ICU follow-ups: need for mechanical ventilation (MV), dialysis, or inotropic agents and the durations of MV and ICU stay. Duration of hospitalization and hospital mortality were also evaluated.

Statistical analysis: Statistical analysis were performed using SPSS 14.0. Data were presented as the mean and standard deviation or number and percentage. The mean data were compared using the Student's t-test. Categorical data were compared using chi-square test or Fisher's exact test upon compatibility. P-values of $<0.05$ and $<0.001$ were considered significant.

\section{RESULTS}

The mean age of the patients was $84.65 \pm 3.36$ years, and there were 50 female patients (69.44\%). The numbers of patients admitted to the emergency room IWH and $\mathrm{OWH}$ were 41 and 31, respectively. Sixteen patients had three or more comorbid diseases such as hypertension, diabetes, congestive heart disease, Alzheimer's disease, dementia, and cerebrovascular disease. The mean waiting time at the emergency room was $74.86 \pm 35.77$ minutes, and the mean time before surgery was $3.09 \pm 1.33$ days. 
Regarding the fracture type, 40 patients showed TFF and 32 showed FNF. PFN was implanted in 38 patients and PHP in 34. RA was administered to 57 patients and GA to 15 . The mean duration of surgery was $60.04 \pm 8.81$ minutes.

Arterial catheterization was applied in $91 \%$ of the patients and central venous catheterization in $76 \%$, intraoperatively or postoperatively. MV was used during ICU follow-up in 18 patients, and the mean MV duration was $0.93 \pm 2.72$ days. Eight patients underwent dialysis treatment and 19 required inotropic treatment. Preoperative blood transfusion was performed in 56 patients. The mean duration of ICU follow-up was $3.41 \pm 3.48$ days and that of hospital stay was $8.34 \pm 5.19$ days. The hospital mortality rate was $16.6 \%$ (Table 1).

Table 1. Demographics and other examined parameters of the patients.

\begin{tabular}{|c|c|}
\hline \multicolumn{2}{|l|}{ Variables } \\
\hline Age (years), mean \pm sd & $84.65 \pm 3.36$ \\
\hline Sex (female/male), n (\%) & $50 / 22(69.44 / 30.56)$ \\
\hline Time of referral to hospital (IWH/OWH), n (\%) & $41 / 31(56.94 / 43.05)$ \\
\hline Duration of waiting at emergency room (minutes), mean \pm sd & $74.86 \pm 35.77$ \\
\hline Time before surgery (days), mean \pm sd & $3.09 \pm 1.33$ \\
\hline Three or more comorbid diseases, n (\%) & $16(22.22)$ \\
\hline ASA (III/IV), n (\%) & $45 / 27(62.5 / 37.5)$ \\
\hline Type of fracture (TFF/FNF), n (\%) & $40 / 32(55.56 / 44.44)$ \\
\hline Anesthesia method (RA/GA), n (\%) & $57 / 15(79.17 / 20.83)$ \\
\hline Surgery method (PFN/PHP), n (\%) & $38 / 34(52.77 / 47.23)$ \\
\hline Duration of surgery (minutes), mean \pm sd & $60.04 \pm 8.81$ \\
\hline Duration of ICU follow-up (days), mean \pm sd & $3.41 \pm 3.48$ \\
\hline Duration of hospitalization (days), mean \pm sd & $8.41 \pm 5.19$ \\
\hline Need for MV, n (\%) & $18(25)$ \\
\hline Duration of MV (days), mean \pm sd & $0.92 \pm 2.72$ \\
\hline Artery catheter, n (\%) & $66(91.66)$ \\
\hline Central venous catheter, n (\%) & $55(76.38)$ \\
\hline Need for inotropics, n (\%) & $19(26.38)$ \\
\hline Need for blood transfusion, n (\%) & $56(77.78)$ \\
\hline Need for dialysis, n (\%) & $8(11.11)$ \\
\hline Mortality, n (\%) & $12(16.67)$ \\
\hline
\end{tabular}

Data are stated as mean \pm standard deviation (mean \pm sd) or patient number and percentage $(n, \%)$.

TFF:trochanteric femur fracture, FNF:femoral neck fracture, GA:general anesthesia, RA:regional anesthesia, PHP:partial hip prosthesis, PFN:proximal femoral nail, ICU:intensive care unit, MV:mechanical ventilation. 
When we grouped the patients as surviving (60) or deceased (12), we found that the time before surgery was significantly longer for the deceased patients than for the surviving ones. Additionally, the need for $M V$, its duration, and the need for inotropic agents were higher among deceased patients than among the surviving ones. Also, the duration of ICU follow-up and hospital stay were longer for deceased patients than for the surviving ones. On the contrary, other parameters showed no significant differences between the two groups (Table 2).

Table 2. Comparison of demographic and clinical data of the surviving and deceased patients.

\begin{tabular}{|c|c|c|c|}
\hline Variable & $\begin{array}{l}\text { Surviving } \\
(\mathrm{n}=60)\end{array}$ & $\begin{array}{r}\text { Deceased } \\
(n=12)\end{array}$ & $p$ value \\
\hline Age (years), mean \pm sd & $84.5 \pm 3.43$ & $85.41 \pm 2.99$ & NS \\
\hline Female sex, n (\%) & $42(70)$ & $8(66.67)$ & NS \\
\hline Time of referral to hospital, IWH, n (\%) & $34(56.67)$ & 7 (58.33) & NS \\
\hline Time before surgery (days), mean \pm sd & $2.85 \pm 1.23$ & $4.33 \pm 1.15$ & $<0.01^{+\times}$ \\
\hline Three or more comorbid diseases, n (\%) & $10(16.67)$ & $6(50)$ & $<0.001 * x$ \\
\hline ASA IV, n (\%) & $19(31.66)$ & $8(66.66)$ & $<0.001 * \times$ \\
\hline Type of fracture, TFF, n (\%) & $32(53.33)$ & $8(66.66)$ & NS \\
\hline Anesthesia method, RA, n (\%) & $47(78.33)$ & $10(83.33)$ & NS \\
\hline Surgery method, PFN, n (\%) & $32(53.33)$ & $6(50)$ & NS \\
\hline Duration of surgery (minutes), mean \pm sd & $58.14 \pm 10.4$ & $62.21 \pm 9.2$ & NS \\
\hline Duration of ICU follow-up (days), mean \pm sd & $2.4 \pm 1.60$ & $8.5 \pm 5.53$ & $<0.01^{+\times}$ \\
\hline Duration of hospitalization (days), mean \pm sd & $8.08 \pm 4.95$ & $10.08 \pm 6.25$ & $<0.01^{+x}$ \\
\hline Need for MV, n (\%) & $8(13.33)$ & $10(83.33)$ & $<0.001 * x$ \\
\hline Duration of MV (days), mean \pm sd & $0.2 \pm 0.54$ & $4.58 \pm 5.38$ & $<0.01^{+\times}$ \\
\hline Need for inotropics, n (\%) & $10(16.66)$ & $9(75)$ & $<0.001 * x$ \\
\hline Need for blood transfusion, n (\%) & $46(76.66)$ & $10(83.33)$ & NS \\
\hline Need for dialysis, n (\%) & $6(10)$ & $2(16.66)$ & NS \\
\hline
\end{tabular}

Data are stated as mean \pm standard deviation (mean $\pm s d$ ) or patient number and percentage ( $\mathrm{n}, \%$ ). †Student's $t$-test, *Pearson's chi-square test, ${ }^{*}$ Statistically significant difference between groups

\section{DISCUSSION}

Our study revealed that the time before surgery, need and duration of $\mathrm{MV}$, need for inotropic agents, and durations of ICU and hospital stays were significantly greater in the deceased patients than in the surviving ones. In addition, $50 \%$ of the deceased patients had three or more comorbid diseases. We found no significant differences in the time of referral to the hospital, surgery and anesthesia methods, and type of fracture, which were examined and reported as effective, among the two groups. 
The presence of comorbid diseases has been reported to affect mortality in elderly hip fracture patients. Meyer et al reported that the presence of two or more comorbid diseases caused a three-fold increase in the mortality rate (14). In a similar study, Roche et al found that the presence of three or more comorbid diseases was a major risk factor for mortality in elderly hip fracture patients (15). Similar to these results, $50 \%$ of the deceased patients in our study had three or more comorbid diseases.

Dailiana et al. reported a hospital mortality rate of $6.9 \%$, and male sex, age of $\geq 85$ years, presence of three or more comorbid diseases, and time before surgery of $>48$ hours increased the mortality rates (10). In our study, the deceased patients had waited longer than the surviving ones before undergoing a surgery.

Kannegaard et al. observed that male sex, advanced age, and presence of comorbid diseases were linked to high mortality rates (9). Liu et al found that the ASA score and postoperative complications were linked to mortality rates (8). In our study, we found that $66.66 \%$ of the deceased patients had an ASA score of IV.

Daugaard et al stated that ASA score, male sex, advanced age, and TFF increased the mortality rates; however, time of referral to hospital had no effect on the mortality rate (11). Foss et al and Schilling et al showed that patients who were

\section{REFERENCES}

1. Kim BH, Lee S, Yoo B, et al. Risk factors associated with outcomes of hip fracture surgery in elderly patients. Korean J Anesthesiol 2015;68(6):561-7. (PMID:26634079).

2. Çetinkaya E, Yavuz U, Lapcin O, et al. Assessment of peroperative parameters affecting mortality in geriatric hip fractures. JAREM 2016;6:183-7. (in Turkish).

3. González-Zabaleta J, Pita-Fernandez S, SeoanePillado T, López-Calviño B, Gonzalez-Zabaleta JL. Comorbidity as a predictor of mortality and mobility after hip fracture. Geriatr Gerontol Int 2016;16(5):561 9. (PMID:25981487). admitted on weekends and holidays had higher mortality rates $(16,17)$. We found that the time of referral to hospital and duration of waiting at the emergency room did not differ between surviving and deceased patients.

Kilci et al stated that the presence of comorbid diseases, high ASA scores, and usage of prostheses with bone cement increased the mortality rates, but anesthesia method had no effect on mortality rate (12). Kopp et al found that type of fracture, time before surgery, and anesthesia and surgery methods had no effect on mortality rates (13). We found that the methods of surgery and anesthesia had similar effects between the two groups. There are, however, controversies regarding this topic in literature.

Our aim was to analyze a specific patient group with high risk, aged $>80$ years, classified as ASA III or IV, and postoperatively monitored at the ICU.

The main limitation of our study was its retrospective, single-center design and the absence of data regarding the patients' mental status and post-discharge conditions. In addition, patient satisfaction and the causes for delayed surgical intervention were not recorded. Therefore, in the light of this illustrative study, we have decided to form a new research protocol for a detailed evaluation of patient satisfaction and causes of delay for surgery.

4- Pugely AJ, Martin CT, Gao Y, Klocke NF, Callaghan JJ, Marsh JL. A risk calculator for short-term morbidity and mortality after hip fracture surgery. J Orthop Trauma 2014;28(2):63-9. (PMID:23872716).

5- Belmont PJ Jr., Garcia EJ, Romano D, Bader JO, Nelson KJ, Schoenfeld AJ. Risk factors for complications and in-hospital mortality following hip fractures: a study using the National Trauma Data Bank. Arch Orthop Trauma Surg 2014;134(5):597-604. (PMID:24570142).

6- Kesmezacar H, Ayhan E, Unlu MC, Seker A, Karaca S. Predictors of mortality in elderly patients with an intertrochanteric or a femoral neck fracture. J Trauma 2010;68(1):153-8. (PMID:19797990). 
7- Koç M, Saçan Ö, Gamlı M, et al. Retrospective Evaluation of Anaesthesia Techniques for Hip Replacement Operations. Turk J Anaesthesiol Reanim 2014;42(3):133-9. (PMID:27366407).

8- Liu Y, Peng M, Lin L, Liu X, Oin Y, Hou X. Relationship between American Society of Anesthesiologists (ASA) grade and 1-year mortality in nonagenarians undergoing hip fracture surgery. Osteoporos Int 2015;26(3):1029-33. (PMID:25300530).

9- Kannegaard PN, van der Mark S, Eiken P, Abrahamsen B. Excess mortality in men compared with women following a hip fracture. National analysis of comedications, comorbidity and survival. Age Ageing 2010;39(2):203-9. (PMID:20075035).

10- Dailiana Z, Papakostidou I, Varitimidis S, Michalitsis S, Veloni A, Malizos K. Surgical treatment of hip fractures: factors influencing mortality. Hippokratia 2013;17(3):252-7. (PMID:24470737).

11- Daugaard CL, Jørgensen HL, Riis T, Lauritzen JB, Duus $B R$, van der Mark S. Is mortality after hip fracture associated with surgical delay or admission during weekends and public holidays? A retrospective study of 38,020 patients. Acta Orthop 2012;83(6):609-13. (PMID:23140106).
12- Kilci O, Un C, Sacan $O$, et al. Postoperative mortality after hip fracture surgery: a 3 years follow up. PLoS One 2016;11(10):e0162097. (PMID:27788137).

13- Kopp L, Edelmann K, Obruba P, Procházka B, Blstáková K, Dzupa V. Mortality risk factors in the elderly with proximal femoral fracture treated surgically. Acta Chir Orthop Traumatol Cech 2009;76(1):41-6. (PMID:19268048).

14- Meyer HE, Tverdal A, Falch JA, Pedersen JI. Factors associated with mortality after hip fracture. Osteoporos Int 2000;11:228-32. (PMID:10824238).

15- Roche JJW, Wenn RT, Sahota O, et al. Effect of comorbidities and postoperative complications on mortality after hip fracture in elderly people: prospective observational cohort study. BMJ 2005;331(7529):1374. (PMID:16299013).

16- Foss NB, Kehlet H. Short-term mortality in hip fracture patients admitted during weekends and holidays. $\mathrm{Br}$ J Anaesth 2006;96(4):450-4. (PMID:16443639).

17- Schilling PL, Campbell DA Jr., Englesbe MJ, Davis MM. A comparison of in-hospital mortality risk conferred by high hospital occupancy, differences in nurse staffing levels, weekend admission, and seasonal influenza. Med Care 2010;48(3):224-32. (PMID:20168260). 